\title{
Resistance of the Eucalyptus Wood in Natura and Torrefied Exposed to the Attack of Cryptotermes brevis
}

Vinícius Resende de Castro ${ }^{1}$, Matheus Perdigão de Castro Freitas Pereira ${ }^{1}$, Paula Gabriela Surdi ${ }^{1}$, Matheus da Silva Berger ${ }^{1}$, José Cola Zanuncio ${ }^{2}$ and Angélica de Cássia Carneiro ${ }^{1}$

1. Departament of Forest Engineer, Universidade Federal de Viçosa (UFV), Viçosa 36570000, Brazil

2. Departament of Entomology, Universidade Federal de Viçosa (UFV), Viçosa 36570000, Brazil

\begin{abstract}
The reduced natural durability and low energy density of eucalyptus wood hampers its use to generate energy. Torrefaction or pre-carbonization, treatment in low oxygenation with temperatures between $200{ }^{\circ} \mathrm{C}$ and $300{ }^{\circ} \mathrm{C}$, accumulates carbon and lignin, decreases hygroscopicity, increases energy efficiency and reduces the wood attractiveness to xylophagous organisms, such as termites. Therefore, this work had as its main aim to study the influence of the roasting temperature on the endurance of the Eucalyptus urophylla wood in natura as well as roasted, both exposed to the attack of dry-wood termites. To the execution of this study, in natura wood chips and torrefied chips (torrefied for $20 \mathrm{~min}$ at the following temperatures: 180,220 and $260{ }^{\circ} \mathrm{C}$ ) were submitted to the dry-wood termite resistance test. In this experiment, termites of the Cryptotermes brevis species were used. After 45 $\mathrm{d}$ of exposure, it was possible to observe that the torrefied treatment presented a greater resistance that consequently increased the endurance when exposed to the termite's attack, observing that the control sample, loss five times more than mass than the chips torrefied at $260{ }^{\circ} \mathrm{C}$. Besides, in the treatment with in natura chips, was observed less mortality of the termites and greater visual damage, confirming the lower durability of such material compared to torrefied chips.
\end{abstract}

Key words: Biomass, heat treatment, termites.

\section{Introduction}

In Brazil, the Cryptotermes brevis, belonging to the Kalotermitidae family, is considered the most relevant due to its easy spreading and ability to attack multiple lignocellulosic objects such as books, furniture, firewood and even wood structures, once its survival depends on materials with humidity levels inferior to $30 \%[1-3]$.

Wood for power generation is chipped, usually in the field or at the factory. These chips are deposited on patios and stored for approximately $90 \mathrm{~d}$ to reduce their moisture when they can be colonized by termites that modify the wood reducing its energy potential.

The termites, due to its degradation capability of organic materials, decrease the woody mass destined to the burn, subsequently decreasing the amount of

Corresponding author: Vinícius Resende de Castro, professor, research fields: wood technology and preservation. energy liberated at the biomass combustion. The resistance of the material to the termite's attack is related with the density and chemical properties, such as resin content, lignin, extractives and others [4].

Undesirable wood characteristics, which may limit its potential for energy production, as well as termite damage, are of concern to the forestry industries in the energy field. The torrefaction increases carbon and lignin in the wood what reduce the damage by termites [5-7]. This treatment increases energy density and reduces the hygroscopicity and attractiveness of the material to xylophagous organisms [5-7].

The objective was to evaluate the resistance of Eucalyptus urophylla chips, after torrefaction, to the biological deterioration by the dry-wood termite $C$. brevis.

\section{Materials and Methods}

E. urophylla wood chips, in natura and torrefied, 
were exposed to the dry-wood termite $C$. brevis according to the method described by the Instituto de Pesquisas Tecnológicas [8], $\mathrm{n}^{\mathrm{o}}$ 1157, with some adaptations.

\subsection{Material Torrefaction}

E. urophylla wood chips from plants with approximately seven years old of experimental plantings were used. These chips were sieved and those that passed through the $31.5 \mathrm{~mm}$ sieve and retained in the $16 \mathrm{~mm}$ sieve were used in the experiment. The selected chips were oven dried at 103 $\pm 2{ }^{\circ} \mathrm{C}$ to $0 \%$ dry basis moisture and torrefied for 20 min at temperatures of 180,220 and $260^{\circ} \mathrm{C}$.

The torrefaction was done with an endless screw reactor, developed in the Panels and Wood Energy Laboratory (LAPEM/UFV) [5]. The metal prototype of this equipment is a semicontinuous screw reactor, which reuses the volatile gases in the heating system (Fig. 1). The primary structure of this reactor has three systems essential to most reactors facilitating the dry torrefaction: (I) transport, (II) heating and (III) cooling.
The first system moves the biomass for the homogenization process being classified as continuous, intermittent or mixed. The second produces and transfers the heat to the biomass under controlled conditions being direct or indirect. The third releases the torrefied biomass within the safe temperature limits.

\subsection{Dry-Wood Termite Durability Test}

Young termites, healthy unwings $C$. brevis were collected manually, from school chairs colonized by this insect.

Eucalyptus chips, torrefied and in natura, were dried in an oven at $103 \pm 2{ }^{\circ} \mathrm{C}$ until constant weight, weighed and placed in a climatic chamber for two weeks for acclimatization at $25 \pm 2{ }^{\circ} \mathrm{C}$ and $65 \% \pm 5 \%$ relative humidity.

Petri dishes, with 39 workers and one C. brevis soldier with $5 \mathrm{~g}$ of dry-wood chip each one with six replicates were used according to the standards of the Instituto de Pesquisas Tecnológicas do Estado de São Paulo (IPT) no 1157 [8].

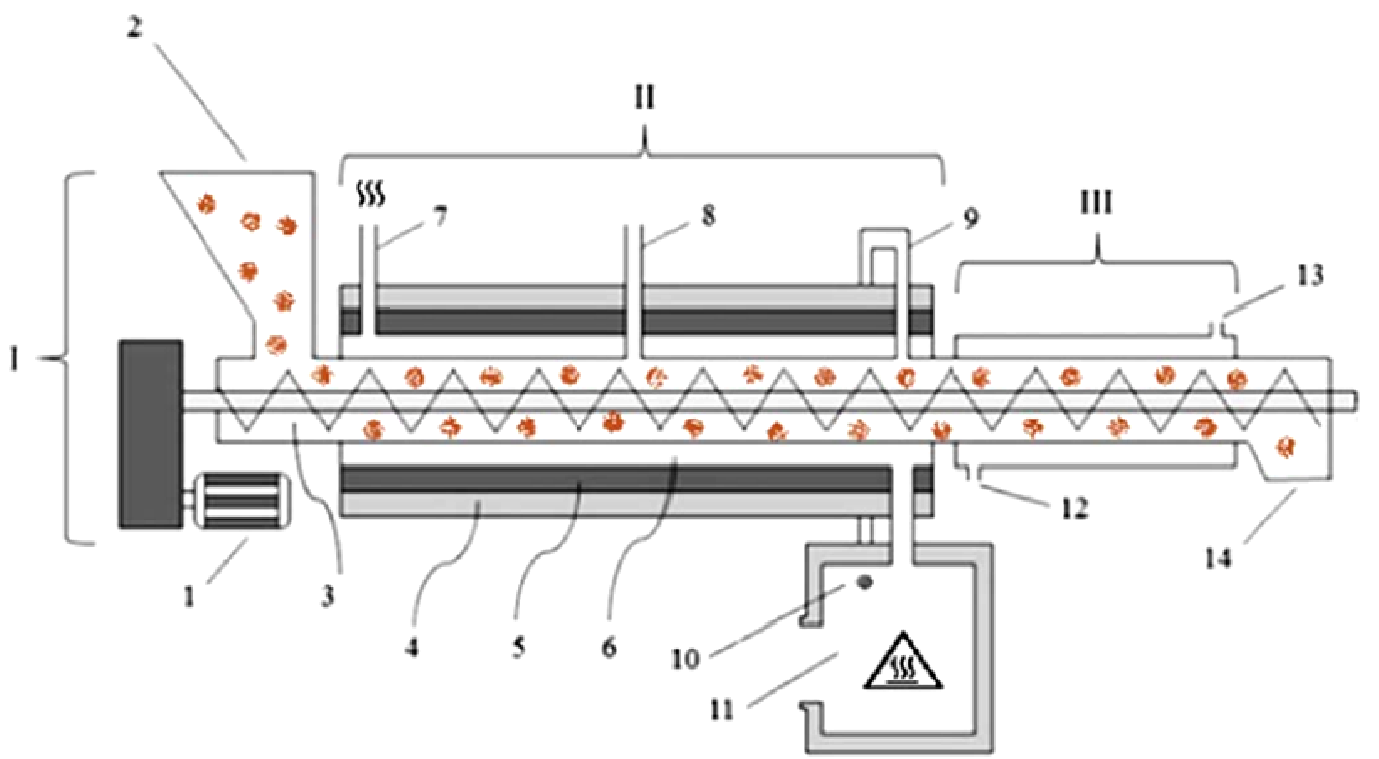

Fig. 1 Lateral view of the layout of the prototype screw reactor developed by a Brazilian university for thermal treatment of lignocellulosic biomass.

I: transport system; II: heating system; III: cooling system.

1: motor; 2: input biomass; 3: worm-screw; 4: insulating layer; 5: refractory layer; 6: heating gas flow; 7: heating gas output; 8: first chimney; 9: second chimney; 10: connection chimney with the burner; 11: connecting burner; 12: water supply; 13: water exit; 14: torrefied biomass exit. 
Holes were drilled in the lid of the Petri dishes to allow gas exchange with the environment. The experiment was maintained in the laboratory $\left(25 \pm 2{ }^{\circ} \mathrm{C}\right.$ and $65 \% \pm 5 \%$ relative humidity). Wood mass loss and termite mortality were obtained after $45 \mathrm{~d}$ and their damage rated from 0 to 4 notes by four examiners. The termite damage was based on the average rating of each examiner according to none (0), superficial damage (1), moderate damage (4), accentuated damage (3) and deep damage (4) following the IPT standards, No 1157-D/D2 DIMAD [8].

\subsection{Experimental Design and Statistical Analysis}

The results of hygroscopic equilibrium moisture, chemical composition and biological assay in relation to the torrefaction temperature of the E. urophylla chips were analyzed in a completely randomized design with four treatments (in natura and three torrefaction temperatures) with six replicates. The averages were grouped with the means test $(p \leq 0.05)$. Statistical analyzes were performed with STATISTICA 8.0 software [9].

\section{Results and Discussion}

The deterioration by the dry-wood termites and the mass losses were reduced for the torrefied material being $59.8 \%$ lower in the wood torrefied at $180{ }^{\circ} \mathrm{C}$ compared to that of the in natura treatment (Table 1). High temperatures chemically modify the wood, degrading the hemicelluloses, food source for termites and generate extractives with fungicides and insecticides properties $[10,11]$, reducing the material hygroscopicity [12] and increase the material acidity, hindering the termite development [2].
Damage caused by $C$. brevis in wood chip mass losses was lower than $1.7 \%$. This may seem low, but the evaluation lasted $45 \mathrm{~d}$ with only 40 termites per plot. Dry-wood termite colonies have, on average, 300 individuals, which would cause greater mass losses [13].

The torrefaction of the material generated/accumulated extractives sufficient to minimize the damages by the dry-wood termite, because substances such as lignin and extractives make the wood more resistant to deterioration by xylophagous organisms [14]. Lignin contents and phenolic extracts produced during the torrefaction process, can reduce the insect food availability and, even without causing their death, reduces the attack intensity and the mass losses. Phenolic extracts have chelating agents, capable of forming complexes with metals and protecting the wood and, when more concentrated, act as natural preservatives (fungicides and insecticides) [10].

The termite mortality rate in the treatments with Eucalyptus torrefied chips increased with an average of $65.2 \%$, higher than that with seven forest species $(58.6 \%)$ [15] and heat-treated E. grandis wood (32.3\%) [16]. The increase in the insect mortality with torrefied chips is due to the high lignin content increase in this process and to the phenolic organic compounds presence from thermal degradation by torrefaction, and reduction of holocellulose as reported for E. grandis wood [16].

Wood damage was recorded in all treatments, indicating that torrefaction did not fully protect the wood. The attack degree decreased with increasing temperature with lower mass losses in torrefaction

Table 1 Average mass losses, mortality and wear grade of the in natura and torrefied Eucalyptus wood chips.

\begin{tabular}{lllll}
\hline \multirow{2}{*}{ Parameters } & \multirow{2}{*}{ In natura } & \multicolumn{3}{c}{ Torrefaction temperature } \\
\cline { 3 - 5 } & & $180{ }^{\circ} \mathrm{C}$ & $220^{\circ} \mathrm{C}$ & $260{ }^{\circ} \mathrm{C}$ \\
\hline Mass loss (\%) & $1.69 \mathrm{a}$ & $0.68 \mathrm{~b}$ & $0.63 \mathrm{~b}$ & $0.33 \mathrm{~b}$ \\
Mortality (\%) & $60.0 \mathrm{a}$ & $67.0 \mathrm{a}$ & $65.5 \mathrm{a}$ & $68.3 \mathrm{a}$ \\
Wear grade & $2.65 \mathrm{a}$ & $2.25 \mathrm{a}$ & $2.18 \mathrm{a}$ & $1.89 \mathrm{a}$ \\
\hline
\end{tabular}

Averages followed by the same letter per line, do not differ by the Tukey test at $5 \%$ probability. 
Table 2 Mass losses, mortality and wear score of the in natura and torrefied Eucalytpus wood chips subjected to the dry-wood termite in the food preference test.

\begin{tabular}{|c|c|c|c|c|}
\hline \multirow{2}{*}{ Parameters } & \multirow{2}{*}{ In natura } & \multicolumn{3}{|c|}{ Torrefaction temperature } \\
\hline & & $180^{\circ} \mathrm{C}$ & $220^{\circ} \mathrm{C}$ & $260^{\circ} \mathrm{C}$ \\
\hline Mass loss (\%) & $5.52 \mathrm{a}$ & $1.30 \mathrm{~b}$ & $0.02 \mathrm{~b}$ & $0.04 \mathrm{~b}$ \\
\hline Wear score & $2.33 \mathrm{a}$ & $0.67 \mathrm{~b}$ & $0.00 \mathrm{~b}$ & $0.00 \mathrm{~b}$ \\
\hline Mortality (\%) & \multicolumn{4}{|c|}{42.00} \\
\hline
\end{tabular}

Means followed by the same letter per line, do not differ by the Tukey test at $5 \%$ probability.

treatment. These results were similar to those obtained with E. grandis wood torrefied at $200{ }^{\circ} \mathrm{C}$ near moderate wear, while this was accentuated in the in natura wood [16].

Chemical components generated during the torrefaction of E. urophylla wood chips may have contributed to lower mass loss, higher mortality and lower wear degree by the termites. Mortality could result from direct action on the termites or from the imbalance caused on their symbionts, since the chemical substances such as terpenoids, terpenes, quinones, polyphenols and other extractives have been widely studied as repellents and/or toxic to termites or their symbionts [17-20]. The microorganisms quantity in the termite intestine may become insufficient to digest cellulose, influencing the eating habits of these insects, which could lead to their death [21].

The weight losses caused by the dry-wood termites was four times higher in the natura chips than on those those treated at $180{ }^{\circ} \mathrm{C}$ for the in vitro and torrefied $E$. urophylla chip test (Table 2), confirming the dry-wood termite food preference for the in natura wood. This may be associated with the lignin concentration in the torrefied material, indicating increased wood resistance to xylophagous termite attack.

The natura wood chip wear was higher than those of the thermally treated ones, with moderate damages in the in natura treatment, superficial in the treatment at $180{ }^{\circ} \mathrm{C}$ and no damage at $220{ }^{\circ} \mathrm{C}$ and $260{ }^{\circ} \mathrm{C}$. The lower feed preference for the torch Eucalyptus chips torrefied at $220{ }^{\circ} \mathrm{C}$ and $260^{\circ} \mathrm{C}$ can be explained by the water adsorption capacity alteration of the chips with increasing temperature leaving the substrate (chipboard) less hygroscopic [14]. The number of water molecules between and inside polysaccharide molecules (cellulose and hemicelluloses) and the hydrogen bonds formed between the polysaccharide hydroxyls of wood and water decrease [7]. The lower hygroscopicity, associated to changes in the chemical composition of the wood with the production of new free molecules that act as insecticides and fungicides and changes in the lignin cross-linking difficult to termites to recognize the food substrate [22], confirms an increase in wood durability with increasing heat treatment [23].

\section{Conclusions}

(1) The E. urophylla wood chips torrefied according to standard are resistant to the dry-wood termite $C$. brevis;

(2) Torrefaction increased the wood chip resistance to the dry-wood termite, with greater efficiency and higher mortality of termites in the treatment of $260{ }^{\circ} \mathrm{C}$;

(3) The dry-wood termites were fed, preferably, on the natura wood.

\section{References}

[1] Arango, R. A., Green III, F., Hintz, K., Miller, R. B., and Lebow, P. K. 2006. "Natural Durability of Tropical and Native Woods against Termite Damage by Reticulitermes flavipes (Kollar)." International Biodeterioration and Biodegradation 57: 146-50. doi: 10.1016/j.ibiod.2006.01.007.

[2] Lepage, E. S. 1986. "Chemistry of Madeira." In Manual of Wood Preservation, vol. 1, IPT, 250.

[3] Scheffrahn, R. H. 1991. "Allelochemical Resistance of Wood to Termites." Sociobiology 19: 257-81. 
[4] Silva, C. A., Monteiro, M. B. B., Brazolin, S., Lopez, G. A. C., Richter, A., and Braga, M. R. 2007. "Biodeterioration of Brazil Wood Caesalpinia echinata Lam. (Leguminosae-Caesalpinioideae) by Rot Fungi and Termites." International Biodeterioration and Biodegradation 60 : 285-92. https://doi.org/10.1016/j.ibiod.2007.05.003.

[5] Cornelius, M. L., Grace, J. K., Ford, P. W., and Davidson, B. S. 1995. "Toxicity and Repellency of Semiochemicals Extracrted from a Dolichoderine Ant (Hymenoptera: Formicidae) to the Formosan Subterranean Termites (Isoptera: Rhinotermitidae).” Environmental Entomology 24 (5): 1263-9.

[6] Paes, J. B., Melo, R. R., and Lima, C. R. 2007. "Natural Resistance of Seven Xylophagous Woods and Fungi under Laboratory Conditions." Cerne 13: 160-9.

[7] Pessoa, A. M. C., Berti-Filho, E., and Brito, J. O. 2006. "Evaluation of the Eucalyptus grandis Thermorectificated Wood Submitted to the Dry-Wood Termite Attack, Cryptotermes brevis." Scientia Forestalis 72: 11-6.

[8] Instituto de Pesquisas Tecnológicas (IPT). 1980. "Methods of Testing and Analysis in Preservation of Wood: Accelerated Laboratory Test of Natural Resistance or Wood Preserved to Termite Attack of the Genus Cryptotermes (Fam. Kalotermitidae).” IPT 1157, 1.

[9] Peralta, R. C. G., Menezes, E. B., Carvalho, A. G., and Aguiar-Menezes, E. L. 2004. "Wood Consumption Rates of Forest Species by Subterranean Termites (Isoptera) under Field Conditions." Revista Árvore 28: 283-9.

[10] Tisseverasinghe, A. E. K., and Jayatilleke, M. P. A. 1973. "Preliminary Study of the Feeding Preferences of the Dry-Wood Termites." Sri Lanka Forestry 11: 13-8.

[11] Van Der Stelt, M. J. C., Gerhauser, H., Kiel, J. H. A., and Ptasinski, K. J. 2011. "Biomass Upgrading by Torrefaction for the Production of Biofuels: A Review." Biomass and Bioenergy 35: 3748-62. doi: 10.1016/j.biombioe.2011.06.023.

[12] Cushnie, T. P., and Lamb, A. J. 2005. "Antimicrobial Activity of Flavonoids.” Int. J. Antimicrob. Agents 26 (5): 343-56.

[13] Mészáros, E., Jakab, E., and Várhegyi, G. 2007. "TG/MS, Py-GC/MS and THM-GC/MS Study of the Composition and Thermal Behavior of Extractive Components of Robinia pseudoacacia." Journal of Analytical and Applied Pyrolysis 79: 61-70. doi: 10.1016/j.jaap. 2006.12.007.

[14] Brocco, V. F., Paes, J. B., Costa, L. G., Brazolin, S., and
Arantes, M. D. C. 2017. "Potential of Teak Heartwood Extracts as a Natural Wood Preservative." Journal of Cleaner Production 142: 2093-9. doi: 10.1016/ j.jclepro.2016.11.074.

[15] Pereira, M. P. C. F., Costa, E. V. S., Pereira, B. L. C., Carvalho, A. M. M. L., Carneiro, A. C. O., and Oliveira, A. C. 2016. "Torrefaction of Eucalyptus Chips for Energy Purposes." Pesquisa Florestal Brasileira 36: 269-75. https://doi.org/10.4336/2016.pfb.36.87.1093.

[16] Bultman, J. D., and Parrish, K. K. 1979. "Evaluation of Some Wood Extractives and Related Compounds as Anti-borer, Anti-fungal and Anti-termitic Agents." International Biodeterioration Bulletin 15: 19-27.

[17] Silva, C. M. S., Carneiro, A. C. O., Vital, B. R., Figueiró, C. G., Fialho, L. F., Magalhães, M. A., Carvalho, A. G., and Cândido, W. L. 2018. "Biomass Torrefaction for Energy Purposes-Definitions and an Overview of Challenges and Opportunities in Brazil." Renewable \& Sustainable Energy Reviews 82: 2426-32. doi: 10.1016/j.rser.2017.08.095.

[18] Maistrello, L. 2018. "Termites and Standard Norms in Wood Protection: A Proposal Targeting Dry-Wood Termites." In Termites and Sustainable Management. Sustainability in Plant and Crop Protection, edited by Khan, M., and Ahmad, W., 261-87. https://doi.org/ 10. 1007/978-3-319-68726-1_12.

[19] Cruz, H., Jones, D., and Nunes, L. 2005. "Wood." In Materials for Construction and Civil Engineering, edited by Gonçalves, M. C., and Margarido, F. Springer International Publishing Switzerland, 557-83.

[20] Knapic, S., Santos, J., Santos, J., and Pereira, H. 2018. "Natural Durability Assessment of Thermo-modified Young Wood of Eucalyptus." Maderas. Ciencia and Tecnología 20: 489-98. doi: 10.4067/S0718-221X2018005031801.

[21] Statsoft Inc. 2007. Statistica Data Analysis System Version 8.0. Tulsa: Statsoft Inc.

[22] Weiland, J. J., and Guyonnet, R. 2013. "Study of Chemical Modifications and Fungi Degradation of Thermally Modified Wood Using DRIFT Spectroscopy." European Journal of Wood and Wood Products 6: 216-20. https://doi.org/10.1007/s00107-003-0364-y.

[23] Guerreiro, O., Cardoso, P., Ferreira, J. M., Ferreira, M. T., and Borges, P. V. 2014. "Potential Distribution and Cost Estimation of the Damage Caused by Cryptotermes brevis (Isoptera: Kalotermitidae) in the Azores.” Journal of Economic Entomology 107: 1554-62. https://doi.org/10.1603/EC13501. 